THE METHOD OF VENOUS OLFAOTCRY TEST ESPECIALLY ON ITS APPLICATION

By

M. ICHIHARA, T. MIYAO, A. KOMATSU, T. KAMIO, K. TAIRA, K. SHIRUKARA, Y. SAKUMA, Y. KANKE, T. MURAYAMA, H. SHIOKAWA, T. KŌDA H. ICHIHARA, H. ASAKA R. ODA AND T. OGAWA

From the Department of Oto-Rhino-Laryngology, Showa School of Medicine (Director: Prof. T. Yamamoto)

On 119 cases which complained chiefly of the oflactory disturbance, venous olfactory test was performed.

The results were as follows:

(1) According to previous olfactcry test, dysosmia was classified into two groups, i.e., hyposmia and anosmia. Each of which, according to that test, is classified into two subgroups, thus dysosmia is classified into four groups, from I-degree to IV-degree.

(2) According to the region of disturbance of sence of smell olfactory disturbance is divided into three types;

(1) morphorgenic type

(2) neurogenic type

(3) combined type

Then a clinical study of signification of each of them was performed.

(3) We stated that there were three types in the process of healing of dysosmia and the careful study of the healing process was helpful to evaluate the prognosis.

\title{
静脈性嗅覚検查法 特にその応用に就いて
}

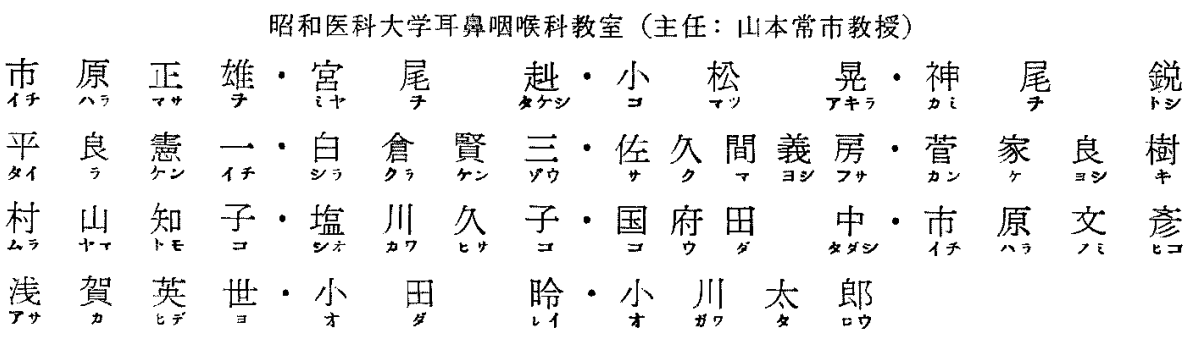

目次

I 楮訔

II嗅喾障害の程度及び部位仁就いて

1. 军娩材料並びに方法

2. 帮験 成箱

(1) 嗅喾障害の程度に就いて

i）嗅喾障害の程度の分類並びに其の判定規準

ii) 率疾患と口関係

(2) 嗅営障害の部位に就いて

i）嗅觉䧛害の部位の分類亚びにその判定規海 ii）鼻疾患との関倸

II 嗅賞障害の治疾過积に就いて

1. 实跧材料並びに方法

2. 実験成縝

IV 総括及び考按

$V$ 結 語

I. 緒言

嗅覚障害の臨床恃固有鼻腔及び副鼻腔の疾患を取扱う 上彺重要な症候の一つであるが，比較的関心が少いため か従来より軽視される㑯向にあつた。私共は本障害の誩 
断及び治繚に関して系統的に研究を行い新知見の開拓に 努めた．その成綨は既に冁告した通りである。本障害を 臨床的に問題とする多くの場合は嗅覚が离度にしか子雨

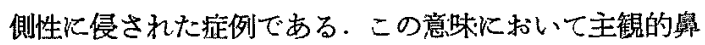
性哭覚に頼つて检查を行 5ッワールデマーケルを矯矢と する従来の舆覚計では湘定不能の場合が往々見られる。 斯かる这例に私共は本法を利同しては心゙满足すべき成果 を得た。文治療を種々行引す治瘉は患者の自覚怔状の好 転により判定を行い管観的の裏付与を欠いている。この

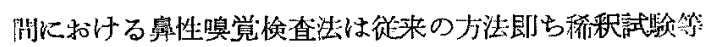

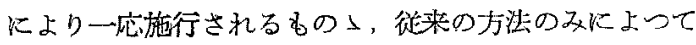
は治瘉過程の分析や今啳の治潦方針を泆定するための詳 細な客観的な 数值を得る事はできない，斯かる観点か ら今回私共は静脈性嗅覚检查を施行して本法が猃断的に 又治癒状態を判定する上に有意である事が判明したので こフに秤告する次第である。

\section{II. 嗅覚障害の程度及び部位に就いて}

1. 包踰材料並びに方法

昭和 33 年 4 月から炤和 34 年 10 月に至る期間に嗅覚

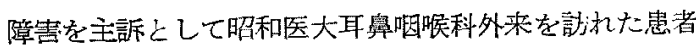
総数 119 例，その中男子 66 例，女子 53 例孝実䖝利料之

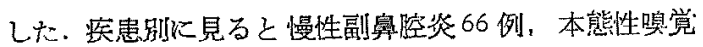
障害 28 例, 慢性萎綰性鼻炎8例, 慢性肥唇性鼻炎6 例,

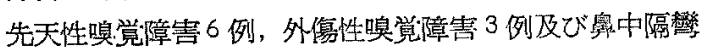
曲症 2 例である. 急性番副鼻腔疾患炕よる場合は程して 释過が短くしか子障害程度は軽微なため恢復前後の状態 を観察するのに適当でないために今回の臾駼では余外

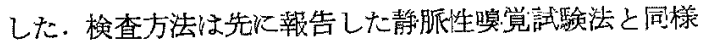
である。

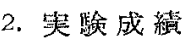

(1) 鮕覚障害の程度に就いて

i）鄓覚·障害の程度の 分類並びに去の判定規準，自覚 的嗅覚は鼻性嗅覚に他ならない，従つてこの湘定を行う には稀釈試験を用いる。稀釈試験に上り暞覚走正常，減 退及び脱失の三段階に分つ，更に静脈性嗅覚試歌を行う

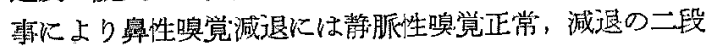
階，喚登脱失には静脈性喚覚減退，脱失の二段階に分類

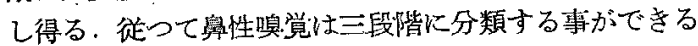
のに対し，青脈性嗅覚を利用すると，第1 表に示寸如く 5 段階に分類し得る。次にとの判定規準であるが，我々 は先ず稀釈鵤駼の成績を基準として行つた，即ち既垠の

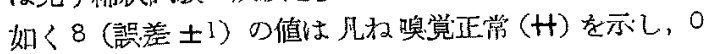
〜6は減退 (十)，0に不感なるのを脱失（一）とした。 次いで静脈性续賞試駼の成績を基準として行う，即らと
の潜伏時間及び持絸時間の测定值特机後者な使用した。 即ら持続㭙間か： 1 分以上を静脈性嗅覚正常 $(\boldsymbol{H}), 30$ 秒 〜1分を娍退（十）文は（土），全く㬇覚の生じないむ のを脱失（一）とした，鼻性唤覚と静脈性喚覚は平行関

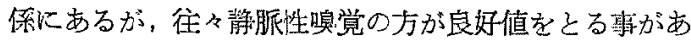
る・このために嗅覚減退を（十）页は（土）の二段階に 分けた。

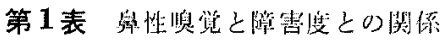

\begin{tabular}{|c|c|c|}
\hline 稀积陚験 & 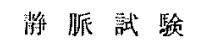 & 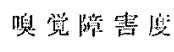 \\
\hline$H$ & 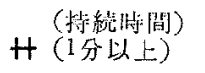 & 常 \\
\hline+ & $\begin{array}{l}+ \text { (1分以上) } \\
+\left(30 e^{\prime} \sim 1 \text { 分 }\right)\end{array}$ & II (伐) \\
\hline- & $\pm(30$ 秒 $\sim 1$ 分 $)$ & $\stackrel{\| l}{N}$ \\
\hline
\end{tabular}

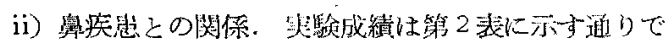

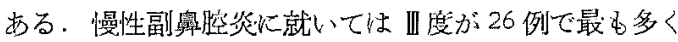
次いで】度19例で更にN及び】度がごれに次いでいる。

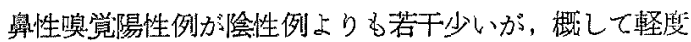
より高度に至る迄種々の段階に広箸囲に見られる。本態 性嗅覚障害は向度が最も多く 15 例を占め，V型9例で これに次ぎ I 及び II 型は少数である，従つて高度に障管

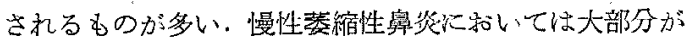

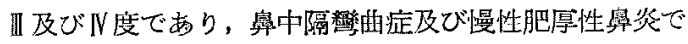
は I 及び】度のみで，II及びV 度は認められなかりた。 先天性嗅覚異常及び外傷性嗅筧障害ではN度のみで他は 觜無ですつた。

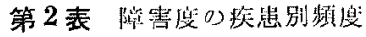

\begin{tabular}{|c|c|c|c|c|c|}
\hline 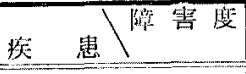 & $\mathrm{I}$ & $\mathbb{I}$ & III & IV & 計 \\
\hline 慢 性融舆腔炎 & 10 & 19 & 26 & 11 & 66 \\
\hline 本態性愻敩障羖 & 2 & 2 & 15 & 9 & 28 \\
\hline 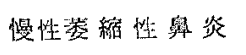 & 1 & & 4 & 3 & 8 \\
\hline 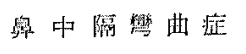 & 1 & 1 & & & 2 \\
\hline 慢性肥厚性奥炎 & 2 & 4 & & & 6 \\
\hline 先天性熄覚璂常 & & & & 6 & 6 \\
\hline 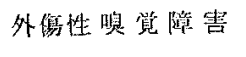 & & & & 3 & 3 \\
\hline
\end{tabular}

(2) 喚覚障害の部位化就いて

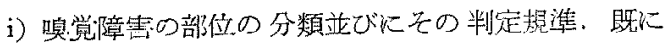

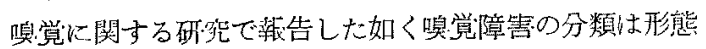
性，神経性及び混合性の三大別に分ち得る。これ走詳述 すれば 
浅賀・小田・小川二静脈性嗅覚檢查法特にその応用に就いて

(a) 形態性嗅覚障害：(1) 舆内形態の異常により嗅素 它含む空気が鮕粘膜に 到着するのが阻止される場合.

(2) 鼾内形態汇異常が認めら水ず嗅感を起すに必要な充 分の臭素量は到着しえても嗅粘膜の機能何等かの病的 変化を生でて鼻性嗅覚のみが障害されたるのである。こ

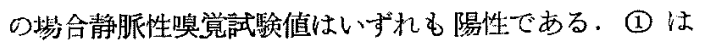
率内形態の整得により (2) は嗅裂部に刘する抗炎挂療汒 等に上り容易に機能を恢復する場合が多い。

(b) 神経性喚覚障害：嗅粘膜感受性が 高度に障害さ

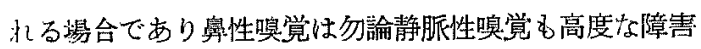
を受汁る、形熊性嗅喾障害 (2) との間には種々の移行型 が存在し, (2) の程度の強いものがこの category に属 する，従来の分類による真性神経性嗅觉障害はこの分類 によると神経性嗅覚障害と形態性嗅覚障害の(2)を含む。 私共の分類では形態性嗅覚障害の (2) を神経性として扱 わなかつたのは治療及び予後の判定上形態性として扱う 方が便利だからである。

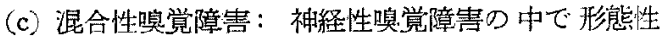
要因の殊に強いむの即ち (a) と（b)の合併せる場合で ある.この際多くは甶内形態的異常に上り二次的嗅 粘膜の障害をきたしたるのと推察される，従つてこの場 合高度の鼻疾患の存在が認められる. 鼻性嗅覚及び静脈 性咱覚恃共渂高度に障害される。上述の関係を表示する 々, 第了表の如くである. 予㖟は混合性, 神経性, 形態 性の順序で不良になる，哭覚障害部位は嗔覚障害程度と 密接な関倸を有し障害の程度を静脈性嗅:賞試駼に上り知 り更に詳細な夓内所見の钼察，X 線検查及び自覚症状，

第 3 表 障害部位々成因

\begin{tabular}{|c|c|c|}
\hline 嗅賞障害 & \multicolumn{2}{|c|}{ 成 } \\
\hline 形態性 & \multicolumn{2}{|c|}{ 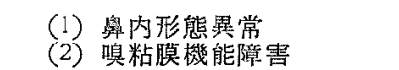 } \\
\hline 削 释性 & \multicolumn{2}{|c|}{ 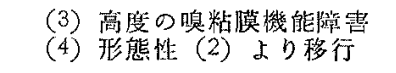 } \\
\hline 波合性 & \multicolumn{2}{|c|}{$\begin{array}{l}\text { (5) 形熊性: (1) + 神経性 (3) } \\
\text { (6) 形態性 }(1)+\text { 补経㛗 (4) }\end{array}$} \\
\hline & \multicolumn{2}{|c|}{ 第 4 表 陪害度と部位との関倸 } \\
\hline & 嗅覚陪害度 & 息覚㒕害部位 \\
\hline & I & 形態 \\
\hline & 』 & 琨合性又は神経性 \\
\hline & III & 熊 \\
\hline & IV & 䄈経性义は叫公性 \\
\hline
\end{tabular}

その他理学的検查を拖行して綜合的に決定せねばなら ない，唤覚障害の部位之程度との関係性第 4 表に示寸通 りである，喚覚減退の場合においては形態性は】度，神 経性は【度，混合性は】度に属し，嗅覚脱失に和いては 形甞性は III 度，神経性はN V 度，混合性はN 度に属する。

ii）鼻疾患との関保 実験成積は第 5 表に示可通りで ある. 慢性副鼻控终では形態性 55 例で大多数を占め混 合性は11 例である. 形態性では嗅覚脱失及び嗅覚減退 が夫タ同じ比率に認められた。慢性鼻炎は形態性, 混合 性が夫^3例及び 4 例で同頻度に認められたが, 混合性 でもその成因は唤粘膜機能障害によるものである，慢性 萎縮性舜炎では形態性 1 例 (この場合 (2)に属する), 神 経幽 7 例である. 文本症では下甲介及び中甲赤注萎縮し て嗅賞にとつても不利益である．既報の如く（嗅党に関 する研究第 1 赫参照) 下甲分はむしろ腫镸傾向にあり嗅 裂部の若干開放している舅腔形態の良い事は圧力試騃に 上り判明している.しかし静脈性嗅覚試䍄の如く強烈な

第 5 表 障害部位の疾患別頻度

\begin{tabular}{|c|c|c|c|}
\hline 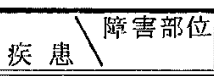 & 形 熊 性 & 神経性 & 混合性 \\
\hline 慢性副嶨腔炎 & 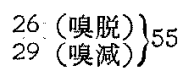 & & 11 \\
\hline 慢性肥厚性鼠炎 & 3 (嗅減) & & 4 (㖵娍) \\
\hline 慢性萎縮性鼠炎 & 1 (嗅隇) & $\left.\begin{array}{l}4 \\
3\end{array}\right\} 7$ & \\
\hline 本態性嗅覚障害 & $\begin{array}{l}3 \text { (䁚脱) } \\
1 \text { (哯減) }\end{array}$ & ${ }_{15}^{9}\{24$ & \\
\hline 先天性嗅覚異常 & & 6 & \\
\hline 外第性嗅覚障害 & & 2 & \\
\hline 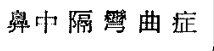 & 1 (咱减) & & 1 (嗅隇) \\
\hline
\end{tabular}

嗅素を用いる検査においては得られた成續が舆内形態に 左程影響されるるのとは考えられず，この意味からも混 合性はあり得ない，本態性墺覚障㕩は 28 例に 認められ たが，このヤ 24 例は神経性，4 例は形態性である. 正 嫦の鼻腔形態有する人は寧ろ極めて稀で多少の病的所 見を有する人が大部分を占める。この意味から䀘腔形態 正常者を決定するねは自覚症状に重点を扣いた，即ら自 覚的に何等の寊症状がなく鼻内形態も嗅覚障害を思わ せ奴程比較的軽度な場合を率内正常と扱ら方がよいと思 5 . 先天性嗅覚異常は6 例, 外傷性嗅覚障害は 2 例示 しいずれる高度の嗅粘模機能障害によるものと考元られ

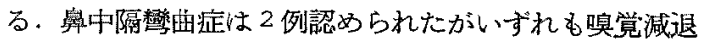
を示し 1 例は形態性他のI例は混合性である。この形態 性に属与る1例は先の成因がのによるるのか文は (2)に 
よるものかを正確に知る事は困難である，舆中隔慗曲の ある症例で嗅覚異常のある時は鼻中隔渏形の位置による 鼻内形熊の意義が異る，例点ば鼻中噪下部においては咱

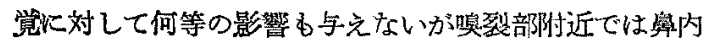
俞流の通路を阻止する事となり，この際沈は (1) の成因 が成立する，他方本症が存在する之唤裂部に生じ九㷋唗 は慢性化文は固定化する傾向があり二次的に暞粘脱機能 を障害せしめる結果をきたす事になる。この怔例ではこ のいずれであるかる明らかにし得なからた。恐らく(1) (2) との両原因以基くもりと考えら机る.

\section{III. 嗅営障害の治痖過程について}

\section{1. 実駼材料並び方法}

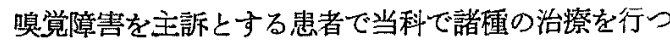

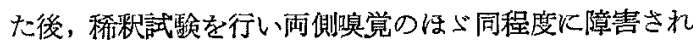
ていて，自覚的に完全治瘑を認めたかあるい㒂しく好 鞋せる症例について以下の観察を詰みた。被検者は第6 表儿示寸如く 14 例使用した。 この中男子 5 例，女子

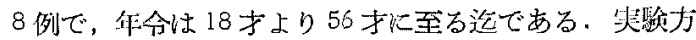
法は既逊の方法と闹様である、静脈性嗅覚試験の潜伏将 間は 4 秒以上及坆ぞの持緢時間は 20 秒以上の治療前後 の変動を有意の変動とした，便宜上静脈性唤覚の発現し

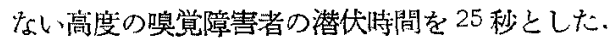

第 6 表 治 挜 過 程 の症 例 (その1)

\begin{tabular}{|c|c|c|c|c|c|c|c|c|c|c|c|c|c|c|}
\hline \multirow{3}{*}{ 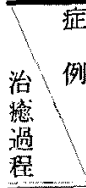 } & \multirow{3}{*}{$\begin{array}{l}\text { 番 } \\
\text { 号 }\end{array}$} & \multirow{3}{*}{\begin{tabular}{|c} 
代 \\
名
\end{tabular}} & \multirow{3}{*}{ 性 } & \multirow{3}{*}{$\mid \begin{array}{l}\text { 年 } \\
\text { 令 }\end{array}$} & \multirow{3}{*}{ 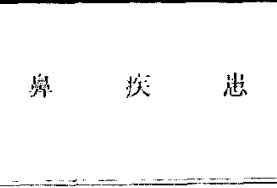 } & \multicolumn{2}{|c|}{ 稀彩試験 } & \multicolumn{6}{|c|}{ 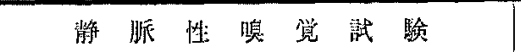 } & \multirow{3}{*}{ 枟 } \\
\hline & & & & & & \multirow{2}{*}{ 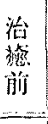 } & \multirow{2}{*}{$\begin{array}{l}\text { 治 } \\
\text { 背 } \\
\text { 後 }\end{array}$} & \multicolumn{3}{|c|}{ 細伏時間（秒） } & \multicolumn{3}{|c|}{ 搏綄时間（仯） } & \\
\hline & & & & & & & & 治漹 & 浯症後 & $\left|\begin{array}{c}2(2) \\
\text { 改善 }\end{array}\right|$ & 治䈁 & 治裳後 & (2) (1) & \\
\hline \multirow{7}{*}{ 醀 } & 1 & |本間 & क & 21 & 慢 性副奥柼炎 & 1 & 7 & 11 & 6 & -5 & 35 & 60 & +25 & 脱失 $\rightarrow$ 減㗨 \\
\hline & 2 & 簐川 & $q$ & 36 & 慢性副鼻腔炎 & 0 & 6 & 25 & 19 & -6 & 0 & 50 & +50 & 脱失 $\rightarrow$ 减退 \\
\hline & 3 & 伊藏 & $\delta$ & 19 & 慢性副舅腔炎 & 0 & 5 & 15 & 11 & -4 & 25 & 65 & +40 & 脱失一正常 \\
\hline & 4 & 中村 & $\hat{\delta}$ & 18 & アレルギー性鼻炎 & 0 & 6 & 18 & 9 & -9 & 40 & 70 & +30 & 脱失 $\rightarrow$ 正常 \\
\hline & 5 & 西尾 & 우 & 56 & $\left\{\begin{array}{l}\text { 本熊性， } \\
\text { 袖経性咱営異宫 }\end{array}\right.$ & 0 & 3 & 25 & 13 & -5 & 0 & 40 & +40 & 脱失一減退 \\
\hline & 6 & 福田 & $\delta$ & 23 & 慢性副畄腔炎 & 0 & 6 & 16 & 11 & -12 & 38 & 61 & +23 & 脱失 $\rightarrow$ 正常 \\
\hline & 7 & 大崎 & q & 52 & 慢性副舁腔炎 & 0 & 5 & 24 & 9 & -15 & 40 & 100 & +60 & 脱失一減退 \\
\hline & & \multicolumn{4}{|c|}{ 平 } & & 5.4 & 19.1 & 11.1 & -8 & 25.4 & 63.7 & +383 & \\
\hline \multirow{4}{*}{$\mathbb{I}$} & 8 & 蓮 & $\hat{o}$ & 48 & \multirow{5}{*}{ 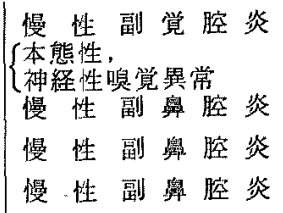 } & 0 & 7 & 20 & 7 & -13 & 65 & 60 & -5 & 脱失 $\rightarrow$ 正常 \\
\hline & 9 & 南 & 우 & 21 & & 0 & 6 & 18 & 11 & -7 & 25 & 40 & +15 & 脱失 $\rightarrow$ 正常 \\
\hline & 10 & 佐藤 & $\hat{o}$ & 32 & & 0 & 3 & 23 & 8 & -15 & 25 & 35 & +10 & 脱失 $\rightarrow$ 減退 \\
\hline & 11 & 宮内 & $\hat{\delta}$ & 26 & & 0 & 1 & 10 & 5 & -5 & 50 & 45 & -5 & 減退一減退 \\
\hline \multirow[t]{2}{*}{ 群 } & 12 & 磯部 & $q$ & 43 & & 0 & 5 & 13 & 6 & -7 & 35 & 50 & +15 & 減退 $\rightarrow$ 减退 \\
\hline & & \multicolumn{4}{|c|}{ 平 } & & 4.4 & 16.8 & 7.4 & -9.4 & 40 & 46 & +6 & \\
\hline III & 13 & 尾沢 & 우 & 21 & \multirow{2}{*}{ 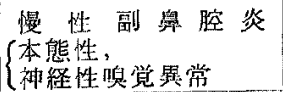 } & 0 & 1 & 16 & 19 & +3 & 30 & 60 & +30 & 脱失 $\rightarrow$ 減退 \\
\hline \multirow[t]{2}{*}{ 群 } & 14 & ज1口 & f & 27 & & 1 & 6 & 7 & 9 & +2 & 45 & 120 & +75 & 脱㚘 $\rightarrow$ 正常 \\
\hline & & & & & 3.5 & 11.5 & 14 & 2.5 & 37.5 & 90 & +52.5 & \\
\hline
\end{tabular}

2. 笑缽成績

治療開始前と治療後の静脈性嗅覚試跧值との関係より 治痛回復機枟に三力式のある事汃解つた。症例は稀积試

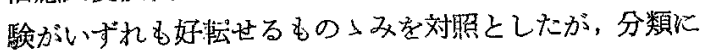

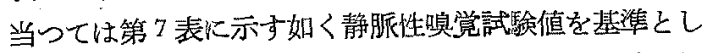

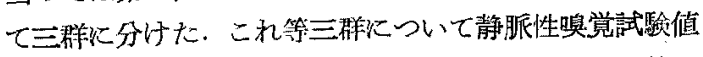

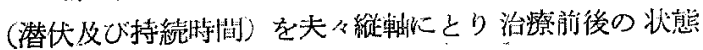

をグラフに示した，即ち第一群は第 1 図に示す如く，潜 伏時問及び持続時間が共见好転している惊例群であり， 第二群は第 2 図に示寺如く，潜伏時間の好転は認められ るが持続時間には有意の好鞋を見ないるのである。第三

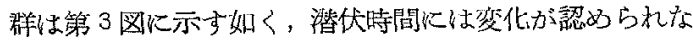

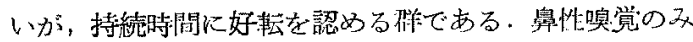
が改善されて静脈性嗅覚の企く改善されたい怔例は見ら 


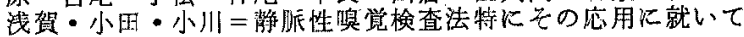

第 7 表治获渦程の分類

\begin{tabular}{|c|c|c|c|c|}
\hline 分 類 & & 試歌 & 潜代時間 & 寺続封:間 \\
\hline 第 & - & 群 & 好 鞋 & 好枟。 \\
\hline 第 & $二$ & 群 & 好 啡 & 不 装 \\
\hline 第 & $\equiv$ & 群 & 不 変 & 好 枟 \\
\hline
\end{tabular}

\section{第一1 图第一群}

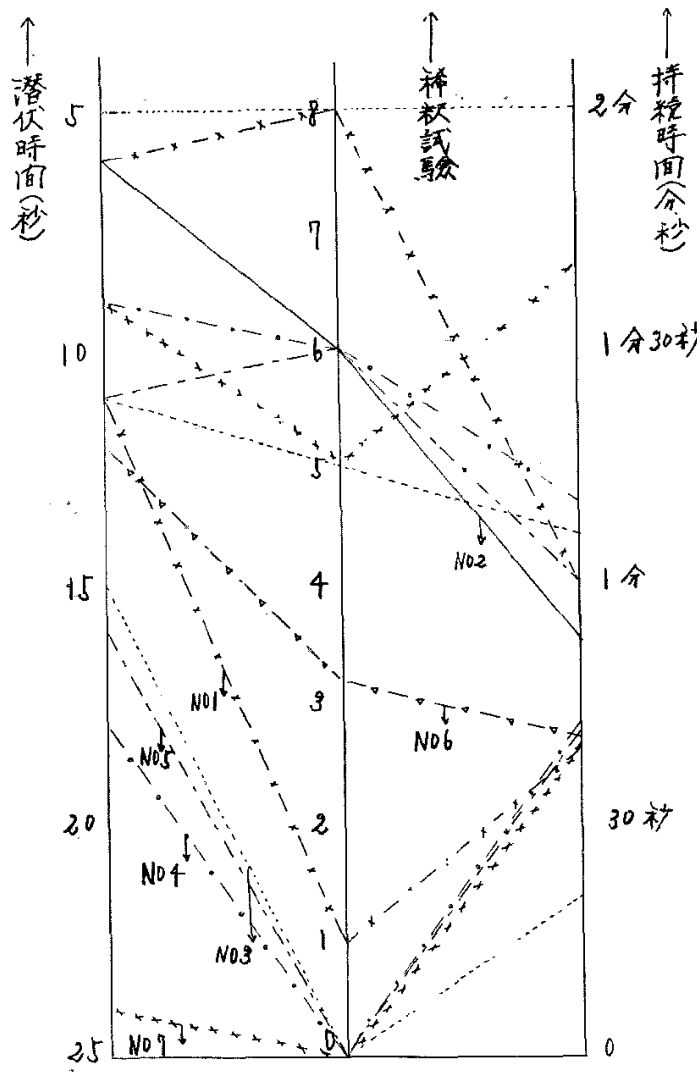

れず䶊疾患の種類別と治瘑回復機転との間には何等相 関関係が見出す事はできなかった，稀鄱試鈳之静脈性嗅

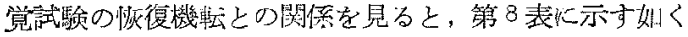
である．唤筧脱失が正常に治完全飞恢復した症例は 7 例

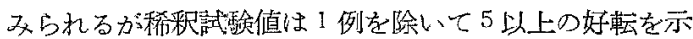
している，潪仗時間で治治前は平均 15 秒，治疮後は 9.1 秒となり改善は 5.9 秒を示した。持続時間では治㺄 前は平均 39 秒，治癒後は 56 秒となり改善は29 秒を示 した。一一著しく恢復はしているが，未だ嗅筧隇退の範 囲以留つている例は 5 例見られたが，稀釈試踰の恢復は
第 2 図第二群

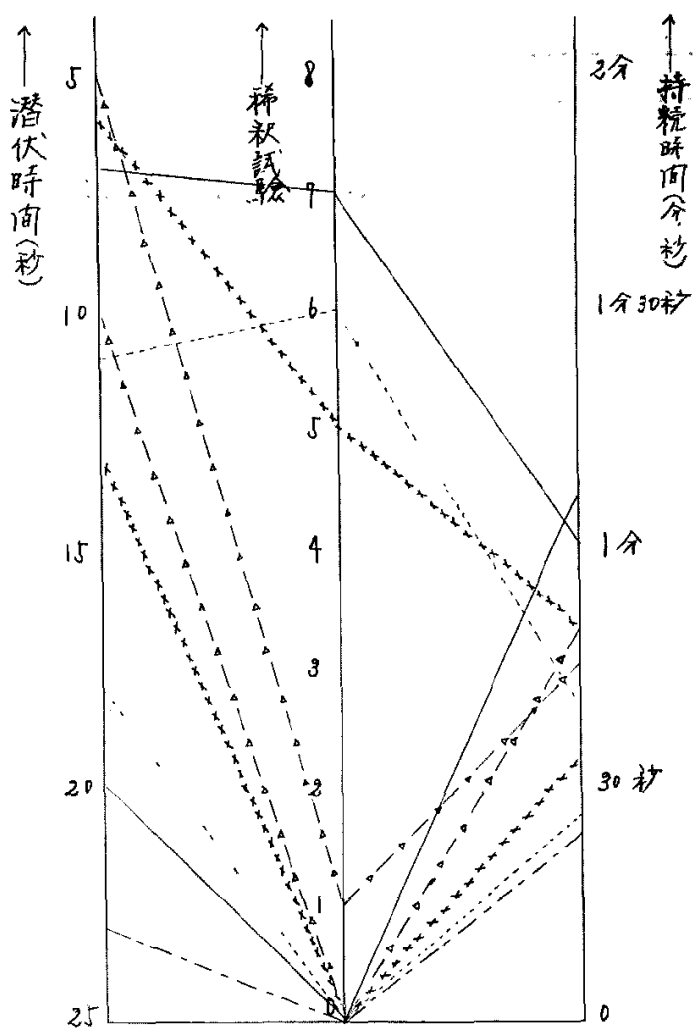

$6 か ゙ 1$ 例， 5 が 1 例， 3 が 2 例， 1 が 1 例となり一定の成 績が得られず，本試糇の及では判定は困難である。これ

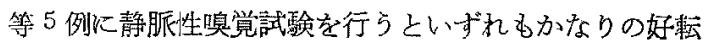

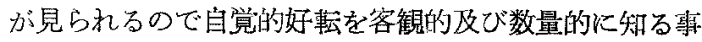
ができる，即ち潜伏時間では治癒前は平均 22.6 秒，治 瘾後は 13.6 秒となり改善は9秒を示した，持続時間は 治療前は平均 19 秒，治痊後は 57 秒となり改善は 38 秒 を示した，嗅覚脱失の完全恢復した症例は不完全恢復の ものよりあ域值の改善が低いが，これ机不完全恢復例に は高度嗔敩障害の好転例が含まれているだめである、上 記の三群の此較を試みると，第一群上第二群比ついての

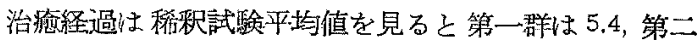
群は 4.4 とをり前者の好転が大きい，潜代時間は第一群

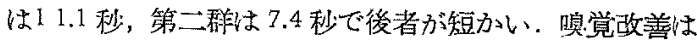
第一群が 8 秒，第二群が 9.4 秒で両者の差は殆ど見られ ない又持続時間は第一群が 63.7 秒，第二群は 46 秒で前 渚が長い，急覚改善は第一群が 38.3 秒，第二群は 6 秒 


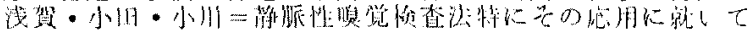

\section{第3圆第三群}

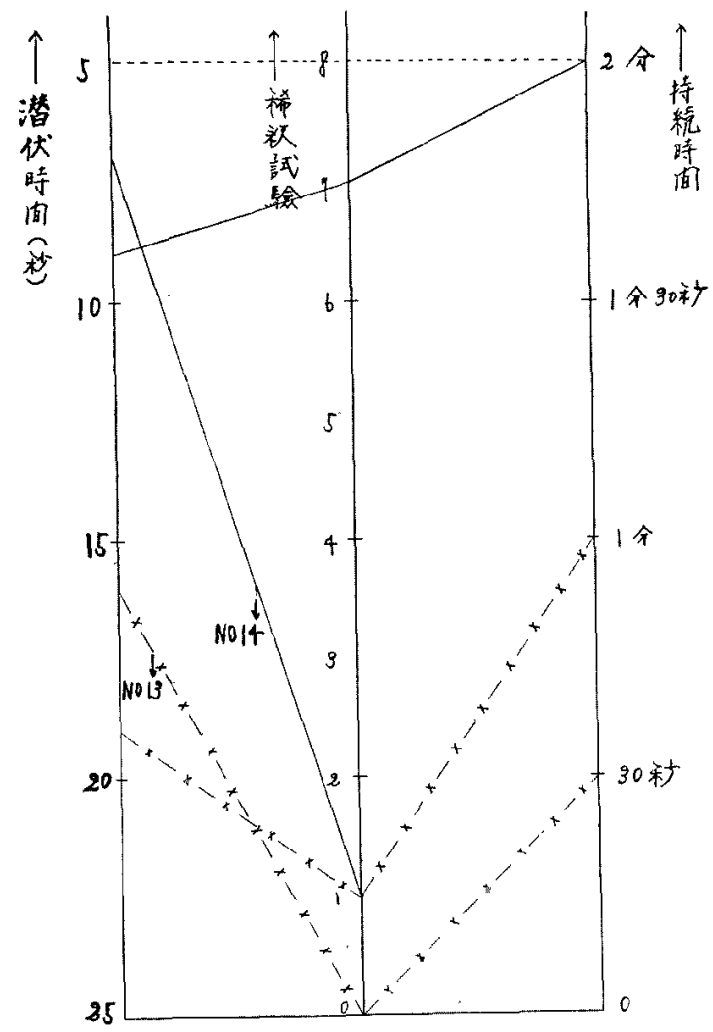

第 8 表 治㗪過程の症例(その2)

\begin{tabular}{|c|c|c|c|c|c|c|c|c|c|c|}
\hline \multirow{3}{*}{ 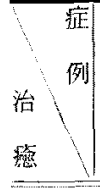 } & \multirow{3}{*}{ 畄 } & \multirow{3}{*}{ 群 } & \multicolumn{2}{|c|}{ 稀 积 試 験 } & \multicolumn{6}{|c|}{ 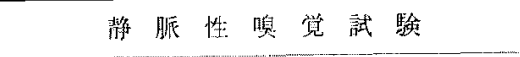 } \\
\hline & & & \multirow{2}{*}{ 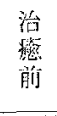 } & \multirow{2}{*}{$\begin{array}{l}\text { 治 } \\
\text { 兟 } \\
\text { 俊 }\end{array}$} & \multicolumn{3}{|c|}{ 潜伙閍閆（䏚） } & \multicolumn{3}{|c|}{ 持糦時闘(秒) } \\
\hline & & & & & 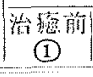 & $\begin{array}{c}\text { (2) } \\
\text { (2) }\end{array}$ & $\begin{array}{l}\text { (2) (1) } \\
\text { 政善 }\end{array}$ & $\begin{array}{c}\text { 治媳前 } \\
\text { (1) }\end{array}$ & $\begin{array}{c}(\text { 治 据 } \\
(2)\end{array}$ & 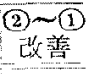 \\
\hline \multirow{7}{*}{$\begin{array}{l}\text { 䚌 } \\
\text { 営 } \\
\text { 关 } \\
\text { ! } \\
\text { 齿 } \\
\text { 常 }\end{array}$} & 1 & I & 1 & 7 & 11 & 6 & -5 & 35 & 60 & +25 \\
\hline & 3 & I & 0 & 5 & 15 & 11 & -4 & 25 & 65 & +40 \\
\hline & 4 & I & 0 & 6 & 18 & 9 & -9 & 40 & 70 & +30 \\
\hline & 5 & I & 0 & 6 & 16 & 11 & -5 & 38 & 61 & +23 \\
\hline & 8 & II & 0 & 7 & 20 & 7 & -13 & 65 & 60 & -5 \\
\hline & 9 & II & 0 & 6 & 18 & 11 & -7 & 25 & 40 & +15 \\
\hline & 14 & III & 1 & 6 & 7 & 9 & +2 & 45 & 120 & +75 \\
\hline \multirow{6}{*}{ 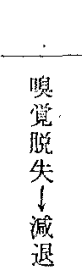 } & 平 & 均 & & 6.1 & 15 & 9.1 & 5.9 & 39 & 56 & 29 \\
\hline & 2 & I & 0 & 6 & 25 & 19 & -6 & 0 & 50 & +50 \\
\hline & 6 & I & 0 & 3 & 25 & 13 & -12 & 0 & 40 & +40 \\
\hline & 7 & I & 0 & 5 & 24 & 9 & -15 & 40 & 100 & +60 \\
\hline & 10 & II & 0 & 3 & 23 & 8 & -15 & 25 & 35 & +10 \\
\hline & 13 & III & 0 & 1 & 16 & 19 & +3 & 30 & 60 & +30 \\
\hline & & \pm & & 3.6 & 22.6 & 13.6 & 9 & 19 & 57 & 38 \\
\hline
\end{tabular}

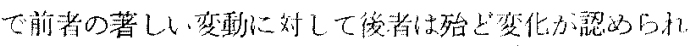

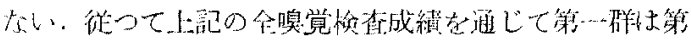

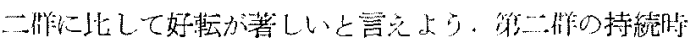

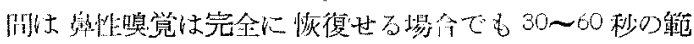
网にある䭪合が多い，第三群の1例は自覚的唤覚は完全

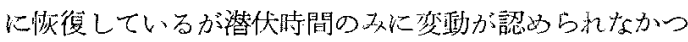

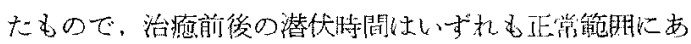
るので治癄を示すには何等の盾原は生じない上思われ

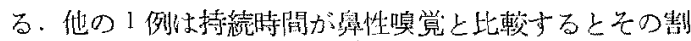
分に強く障畵されている。これは形態性因于が强いため に起つたのであつて適切な治療により自覚的の好転之斯

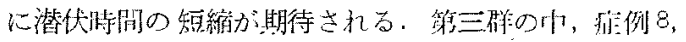

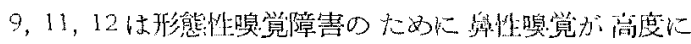

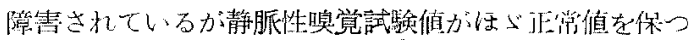
ている、しかして治滰により形態性因子か除去された

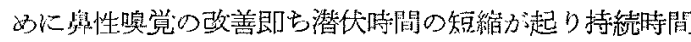
と可行関係が保つようになつたもの上假秎される。但し

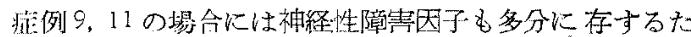

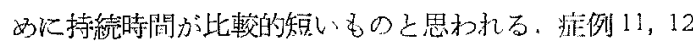
は完全恢復には至らないが自觉的にや小好転を思水せた

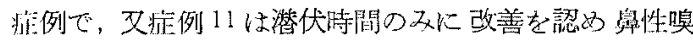

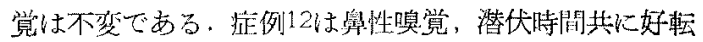
が認められたもので症例11に比し改善率が箸しい，乙 かし，再例共に持続時間は不装であるので再笔の傾向が 㫕られ，更に治療を必琴とする症例と据釈する事ができ る.

\section{IV. 絵括及び考按}

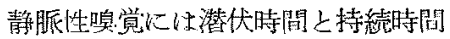
とがありそのいずれの時間も睤性嗅覚

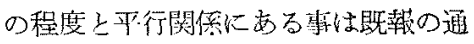

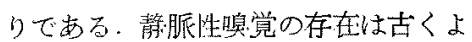
り知られているが，杂机の誉断面人の 応用は未だ系統的洒研究がなれてい

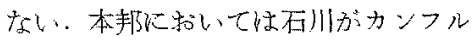

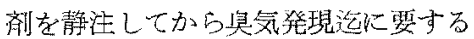
㭙間を潜伏時間と称して論じてある が，私其が傕断的により垂視している

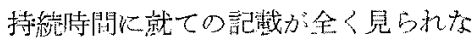
い告力疲学現象として簡単に取扱っ ているに過热ない，最近の工藤・太四

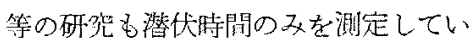
る。従つて過去の篹政加らの知見のみ では静脈性喚覚の謞断的值は少くこの 
ために本検查の竞及が行われなからたものと推察する。

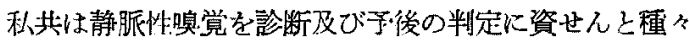

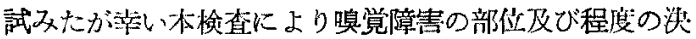
定及び予後の判定等について卵が有意な結論を得た。先 ず潜代時間及び持続時間の意義について述べる. 両測定 值は同一被検者においては検査の反復により著しい差異 を生じないので循環時間，フリナミン分泌速度及び分泌 量は呼吸循環器疾患がなけれぱ日によつて左程の影算は ないと思われる。この理由から測定値に変動が見られた

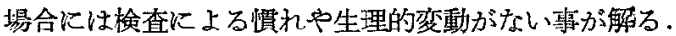
潜伏時閒も要約する因子は鼻性嗅覚に他ならないのであ るから鼻性嗅覚の改善に伴つて本測定值も良好な值を得 る事が栲えられ，この事快症例によく示されている。庈 百，持続時間は正常㖵覚者においては鼻性嗅覚とほ心゙和。 行関係にあるが, 病的者では鼻性嗅覚及ご潜伏時間の变 動化つて率化する場合としからざる場合とがある。後 者では治潦に良く区応与る例が多く，か」る例は後述の 形態性嗅覚障富の場合に多く見られる。概して持続時間 は諸種の実験成績から見ると疲労現象の影響を受け易い 欠点があるが，フリナミン分泌速度，分泌量により定め られるべきものと思われ，分泌速度及び分泌量が大であ る事は，換言すれば嗅糊堂の機能がよい事とも考方ら れ，私共が称える搝糊膜の感受性を示寸ものである。こ の事は治潦面より観察しても持続時閒の長い，程予後は良 いが短いむのは予後が悪く，たとえ治療しても再発の傾 向が強い等の成績からも，うなづかれる．結論的には潜 伏時間は鼻性咱覚の上小屯の程短く，持続洔間は疲労速 度及び心肺機能の影響を受ける久点こそあれ嗅粘膜感受 性と平行関係にあるので治潦機転を簡明する指針になり

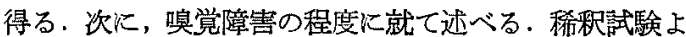
りその測定值を大別すると，喚覚正常，減退及び脱失の 三段階に分ち得る。静脈性嗅営を利用すればこれ等三段 階にも諸種の程度がある珘は既に第 1 表に示した通り

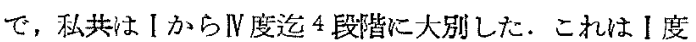
からN度に進むに徒い、障害度が大なる事を示したるので ある，私共が嗅覚障害をかつる4段階に分類した根拋は

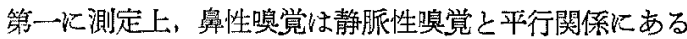
㧰，第二に治療上，段階の進さ程予後が悪くなる傾向が

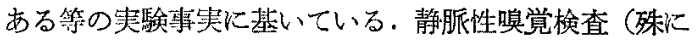
持続時間）により治疻の状態に 3 方式のある车が解つた が治瘺の経過を見るには稀釈試験のみ利用するよりも本 法を行つた方がより正確に 観察する等が 可能であり， 又, 再発傾向の有無, 治瘾機転及び治療方針の決定を追
求する，上に好都合である，勫性嗔覚障害の恢復状態は主 として我国の文献に 若干見る标ができる，大沢 (1958) は潜伏時閒の辰い子の程子後不良で嗅賞が恢復に问亏惦 には短くなる傾向か゚あると述べ，石川（1938）は潜伏時 間が長いか文は副作用が少い程鼻性嗅覚障害の予後が不 良であると述べている，文恢復状況は最初は比較的強烈 な搝覚のみを嗅感寸るようになり，次第に普通の嗅素を

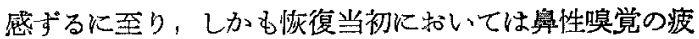
労性が亢進していると述べている．更に氏は舅性噮営障

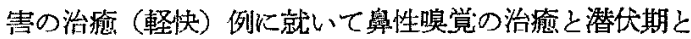
の関係を迫究した。即ち嗅覚減退 8 例，唤覚脱失，嗅党 異常及び悪臭症各»! 例計 14 例中潜伏期と注射時間之 の此が回を追うに従って減少するものが大多数で, 同一 のものか嗗覚脱失及び嗅覚異常各タ1例，却つて增大し たものが㖵覚減退に1例見られたと思らと述べ，石川は 私共の潜伏時間延長，持綕時間短維の事を指しているす のと思われるが私共はこ机等を数量的に簡潔に表現し得 たのである. 又治㾉と潜伏期との問に矛盾した数値が出 ているのは潜伏時閒のみる測定したものであるからで持 続時間を同時に測定すれば斯かる誤差を少なくする事が できよう。梴行性嗅覚を応用して嗅覚を定量的に测定す る方法は最近，工藤，河村，太田等により報告されてい る. 太田（1947）は工膆とほが同様の方法でフリナミン 注射液 $1 \mathrm{cc}$ を $4 \mathrm{cc}$ の葡萄粘に混合し，これを $5 \mathrm{cc}$ の注 射器で被烚者任安静呼吸をさせてから $1 \mathrm{cc} 5$ 秒の速度 で注射し，初めて嗅覚の起つた時の注射量をその人の惧 覚檤とした，氏は慢性副鼻腔炎患者29 例江就て 鼻性血 行性咱覚検查の比較を行つた所, 自覚的嗅覚障害の無い むのは 29 例中 7 例でそれ等の鼾性嗔覚検査で正常々認 めたものは 1 例のみで血行性で正常と認めたものは3 例, 自覚的嗅覚障害のある者 18 例の 鼻性検查では全例 に障害を認めたが血行性ではその中 3 例が正常であつ た．この正常值をとる理由として氏は䦪値に幅の変動が あるためであると推考している.更に鼻性嗅覚検査で䦵 側共全く嗅覚の無いもの 4 例, 血行性嗅覚検查では 2 例

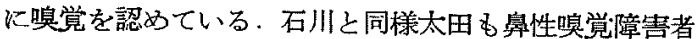
でも血行性嗅覚がなお存在する事を諗めているが私共は この事実を高度㗘覚障害者の検查に応用した. 工藤, 太 田等が求めている閾值は石川や私共の潜伏時䦓に相当す

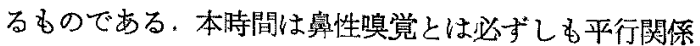
にない症例も見られるので本㭘査のみでは嗅覚測定のみ ならず障害の䛦断及び予後の判定に資するには不十分で ありこの点私共は溴粘膜感受性を表わす持続時間を問題 


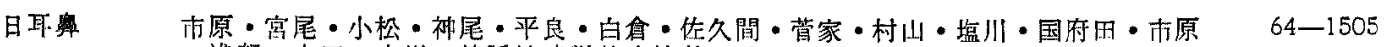

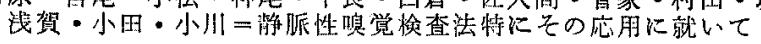

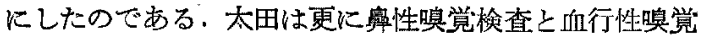
検查の值はよく平行している事から向行性嗅覚検查が前 诸と同様にその機序は呼吸性嗅覚が第一義的であり，と の值は呼吸性唤覚障害度を表わしていると考光てこの点 から血行性検查は鼻性检查に代用しらるすのであると述 ヘているが本法の診断面への応用は未だ示されていな い. 静脈性㖵覚検査は左右の鼻膑に嗅覚差の推定される 例には更に鼻性嗅覚検查を併用する必要があり，本法は 万能でない事は諭を俟たない。

\section{V. 結語}

暞覚障害を主訴として来院した患者 119 例に就き，静

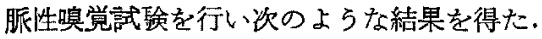

(1) 従来つ咱覚検查に上ると㬇覚障害の程度を減退及 び脱失の二理類に分類しらるが，静脈性嗅覚試験を用い ると，夫々を更に2 段階に細別する事が可能となり，程 度の軽い順より I 度より N 度迄分類を行つた。

（2）疾患別に見ると，慢牲副鼻檫炎では各段階におい て見られるが，本態性嗅覚異常では似及゙可度において $86 \%$ 認められ，先天性及び外傷性哃覚異常では觜 $\mathrm{N}$ 度で あつた.

（3）嗅覚障害つ部位を静脈性郻覚試験を使用する事に より，形態性，神経性及び湿合性の三程類に大別し得， 更に各障害部位の意義に就き臨床的考察を行つた。次に 障害部位と程度の関係に就いて見ると，咱覚減退の場合 においては形態性は I 度, 神経性及び湜合性は II 度に属 し，鮕覚脱失に和いては形態性は四度，神経性及び混合 性 $\mathbb{V}$ 度に属する。

（4）搝覚·障害の治癒過程には三方式があり，即ち第一
群は潜伏㭙間及び持続時間共に好転せるものであり，第 二群以潜快侍間のみ好転せるものであり，第三群は持続 㭙間のみ好転せるものである，页に治癒過程を観察する

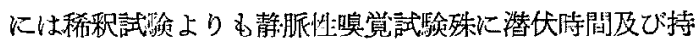
続時間双万を測定して初めて正確に文数量的に可能であ る事が解つた。

\section{文献}

1) Bednär, Rangfelder: Über des intravenöse(hämatogene) Richen M. f. O. s. 1133,1930 . 2) 石川: 血行性咱覚と嗅覚障害の治潦に就て, 日耳会, 44, 3, 725,1938 .3) 工藤, 传藤：慢性副奥膑炎と血行性嗅 筧，日耳会， $55 ， 5,777,1947$ 4) 工藤：嗅覚機能に 対劣る実験的研究, 日耳会, 55, 6, 997, 1947, 5) 市 原，他：咱覚に関する研究第 1 報，咱覚計に関する文 献的考察, 日耳会, 62,6,1959。6) 太田：奥性嗅営 検查と血行性嗅覚検查の比较, 耳鼻㸶呢科，31，9，675, 1959.7) 市原, 他：静脈性咱覚試験法に就て, 日耳, $63,6,1460,1960$. 8) 市原, 他: 嗅覚検查法に就て, 日耳, 63，6，1469，1960.99)佐久間：嗅営䧛害に関 する猃断的研究，日耳，63，6，1505，1960，10）市原，

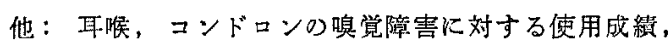
$32,11,983,1960$.

釉稿に当り恩師山本教授の御指導, 御校閲を感謝 する。

(本諭文の要旨は日本耳鼻咽喉科学会第378 回関 東地方会において演述した)。

（原稿到着 $=$ 昭和 36.3 .6 日） 